\title{
Single Oral Dose Toxicity Test of Water Extracts of Radix Araliae Cordatae in ICR Mice
}

\author{
Sae-Kwang Ku*, Moon-Jeong LeEM and Jei-Man Ryu \\ Central Research Laboratories, Dong Wha Pharm. Ind. Co. Ltd., Anyang, 430-017, Korea
}

(Received 29 May 2007; Accepted 20 June 2007)

\begin{abstract}
The object of this study was to evaluate the acute toxicity of lyophilized water extract of Radix Araliae Cordatae (RA) in male and female mice. The extract was administered to female and male ICR mice as an oral dose of $2000 \mathrm{mg} / \mathrm{kg}$ (body wt.) according to the recommendation of KFDA Guidelines. Animals were monitored for the mortality and changes in body weight, clinical signs and gross observation during 14 days after dosing, upon necropsy, organ weight and histopathology of 12 principle organs were examined. As results, we could not find any mortality, clinical signs, changes in the body weight and gross findings except for increases of hypertrophy of lymph nodes in male RA extracts-dosing group. In addition, no RA extracts-treatment related abnormal changes in the organ weight and histopathology of principle organs except for some sporadic accidental findings. The results obtained in this study suggest that the RA extracts does not cause any toxicological signs. The LD $_{50}$ and approximate LD of RA extracts in both female and male mice were considered as over $2000 \mathrm{mg} / \mathrm{kg}$.
\end{abstract}

Key words $\square$ Radix Araliae Cordatae, Aralia continentalis Kitagawa, Water extracts, Single oral dose toxicity, Histopathology

\section{INTRODUCTION}

Radix Araliae Cordatae (RA) is a herbal drug consisted of the dried root-barks of Aralia continentalis Kitagawa, and has been used as a Korean traditional folk medicine for treating or preventing of various diseases, especially for inflammatory diseases (Park et al., 2005), and the analgesic and anti-inflammatory effects of RA are relatively well documented (Lee et al., 1995; Park et al., 2005) with the chemical components (Wang et al., 1989)

As increase of the concern in the functional food and well being in life, the demands and consumption of functional food originated form natural sources are increased (Lee et al., 2003). However, the toxicological aspects about these natural originfunctional foods has been neglected because of the reasons that they has been used as various purpose for long times. Therefore, it is considered that more detailed and systemic toxicological studies should be performed to control the abuse and potential toxicities even if they have been used as traditional folk medicine. The toxicological studies about RA also have

*Corresponding author

Tel: $+82-31-445-2485, \quad$ Fax: $+82-31-446-9556$

E-mail: gucci200@hanmail.net been neglected and the reports dealing the toxicological aspects of RA extracts, even if the basic single dose toxicities in rodents are also seldom.

The objective of the present study, therefore, was to obtain the primary safety information about RA extracts, lyophilized water extract of dried root-barks of Aralia continentalis, and to further clarity their safety for clinical use.

\section{MATERIALS AND METHODS}

\section{Animals and husbandry}

Each of ten female and male ICR mice (6-wk old upon receipt, Charles River, Japan) was used after acclimatization for 8 days. Animals were allocated five per polycarbonate cage in a temperature $\left(20-25^{\circ} \mathrm{C}\right)$ and humidity $(45-50 \%)$ controlled room. Light : dark cycle was $12 \mathrm{hrs}: 12 \mathrm{hrs}$, and feed (Samyang, Korea) and water were supplied free to access. All animals were overnight fasted before dosing and terminal necropsy. Animals were marked by picric acid. The experimental protocols were conducted in accordance with internationally accepted principles for laboratory animal use and care as found in the Korea Food and Drug Administration (KFDA) guidelines. 


\section{Administration of RA extracts}

Aqueous RA extracts (dried root-barks of Aralia continentalis Kitagawa: yield $=16 \sim 18 \%$, extracted by Dong Wha Pharm. Ind. Co., Korea) were prepared by routine methods using rotary vacuum evaporator (Lab. Camp, Korea) and programmable freeze dryer (IlShin Lab., Korea). RA were purchased from Buyoung Pharmaceutical Ind. Co. (Seoul, Korea) collected in China after confirm the morphology under microscopy. Powders of RA extracts are light yellow powder, and they were stored in a refrigerator at $-20^{\circ} \mathrm{C}$ to protect from light and degeneration. RA extracts were soluble up to $100 \mathrm{mg} / \mathrm{ml}$ concentration level and appeared to be a light yellowish solution. The animals were grouped into 4 with 5 mice per group upon receipt. RA extracts have been used as folk medicine and ingredients of medicinal food for long times, and no revealed toxicological data was available, the highest dosage level was selected as $2000 \mathrm{mg} / \mathrm{kg}$ according to the recommended by KFDA Guidelines (2005-60, 2005), the limited dosages. In addition, a vehicle control group was added as listed in Table I. Animals were given an oral dose of RA extract in water 100 $\mathrm{mg} / \mathrm{ml}$ using a zonde attached to a syringe of $1 \mathrm{ml}$ after overnight fasting (about $18 \mathrm{hr}$, water was not restricted). Food and water were restricted further for about $3 \mathrm{hrs}$ after dosing.

\section{Abnormal behavior, clinical sign and body weight}

All abnormal clinical signs and behaviors were recorded before and after dosing at least twice a day based on the functional observational battery test (Irwin, 1968; Dourish, 1987). Body weights were measured on the day of dosing (Day 0) prior to treatment, 1, 2, 7, 13 and 14 days after dosing. In addition, to reduce the erratum originated from individual body weight differences of animals at initial dosing, body weight gains during Day 0 Day 7, Day 7 Day 13 and Day 0 Day 13 was also calculated based on measured body weight at each points.

\section{Necropsy}

Necropsy was done on the animals found dead during the experiment and all animals were subjected to terminal necropsy at the end of experiment at Day 14 after overnight fasting (about 18hr, water was not restricted). Animals were euthanized by carbon dioxide and gross necropsy was performed.

\section{Organ weight measurements and sampling}

The absolute organ weight was measured and then relative organ weight ( $\%$ for body weight) was calculated. The following organs were collected for histopathological observation.

Measured and sampled organs: lung, heart, thymus, left kidney, left adrenal gland, spleen, left testis or ovary, liver, splenic lobe of pancreas, brain, left epididymis or total uterus and left popliteal lymph node.

\section{Histopathology}

Samples were fixed in $10 \%$ neutral buffered formalin. After $18 \mathrm{hrs}$ of fixation, paraffin embedding was conducted and $4 \mu \mathrm{m}$ sections were prepared by routine histological methods. Representative sections of each specified organs were stained with hematoxylin-eosin for light microscopical examination.

\section{Statistical analyses}

Changes of body weights and organ weights were analyzed by Mann-Whitney U-Wilcoxon Rank Sum W test (MW test) compared to those of vehicle control. $\mathrm{LD}_{50}$ was calculated by Probit method. Statistical analyses were conducted using SPSS for Windows (Release 6.1.3., SPSS Inc., USA) and a $p$-value of less than 0.05 was considered to be a significant difference.

\section{RESULTS}

\section{Mortality rate}

No sudden mortality was detected in all dose levels tested. All animals $(5 / 5 ; 100 \%)$ survived in all dose levels tested including vehicle control.

\section{Abnormal clinical signs detected}

In this study, no RA extracts-treatment related abnormal

Table I. Experimental design used in this study

\begin{tabular}{cccc}
\hline Group & Sex & No. of animals & Total Dose $(\mathrm{mg} / \mathrm{kg})$ of Radix Araliae Cordatae extracts \\
\hline G0M* & Male & 5 & 0 \\
GRAM & Male & 5 & 2000 \\
G0F* & Female & 5 & 0 \\
GRAF & Female & 5 & 2000 \\
\hline
\end{tabular}

*Vehicle control; distilled water $20 \mathrm{ml} / \mathrm{kg}$ as vehicle in this study; All test articles in vehicle were once orally dosed. 
clinical signs were observed during observation periods regardless of male and female mice except for hair loss that was randomly detected from 5 days after dosing including vehicle control groups (Table II).

\section{Changes of body weights}

No significant changes in body weight were detected compared to that of vehicle control in all dose levels tested (Table III).

\section{Changes of organ weights}

No significant changes in the absolute and relative weight of 12 principle organs were observed in all dose groups compared to that of vehicle control (Table IV, V).

\section{Necropsy findings}

No significant changes in the gross findings of 12 principle organs were observed in all dosing groups compared to that of vehicle control except for increased incidences of the hypertrophy encounted in RA extracts female group. Some animals showed sporadic accidental findings such as congestion spots of lung, atrophy of thymus, cyst and discolorization of kidney and spleen atrophy (Table VI).

\section{Histopathological findings}

No significant histopathological findings were observed in 12 principle organs of all dose groups tested compared to that

Table II. Clinical signs observed in female and male mice after a oral dose of RA extracts

\begin{tabular}{ccc}
\hline \multicolumn{2}{c}{ Group ID } & Clinical signs \\
\cline { 3 - 3 } MALE & G0M & Hair loss \\
& GRAM & $2 / 5(40 \%)$ \\
& FEMALE & $1 / 5(20 \%)$ \\
& GRAF & $3 / 5(60 \%)$ \\
& GRAF & $1 / 5(20 \%)$ \\
\hline
\end{tabular}

Values are expressed as observed animals/total observed animals $(\mathrm{n}=5)$ (percentages)

Table III. Body weight gains in female and male mice after once orally dose of RA extracts

\begin{tabular}{ccccc}
\hline \multirow{2}{*}{ Group ID } & \multicolumn{3}{c}{ Interval } \\
\cline { 3 - 5 } Mal 0 ${ }^{\text {a }}$ - Day 7 Day 7- Day 13 Day 0 - Day 13 \\
\hline GAM & G0.30 \pm 3.68 & $3.68 \pm 1.21$ & $9.12 \pm 1.63$ \\
& GRAM & $10.60 \pm 0.84$ & $4.08 \pm 0.54$ & $9.76 \pm 0.67$ \\
\hline FEMALE & G0F & $5.42 \pm 0.98$ & $1.94 \pm 1.13$ & $4.10 \pm 0.78$ \\
& GRAF & $4.78 \pm 1.01$ & $3.56 \pm 1.64$ & $5.94 \pm 1.86$ \\
\hline
\end{tabular}

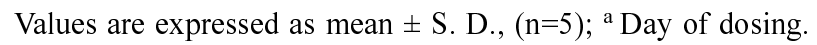

of vehicle control except for hypertrophy of lung alveolus wall with hemorrhage (Fig. 1), focal necrotic foci and fatty changes in liver (Fig. 2) (Table VII).

\section{DISCUSSION}

In the present study, we investigated the acute toxicity of single oral dose with RA extracts, lyophilized water extract of dried root-barks of Aralia continentalis to mice as a part of the safety test. In order to observe $50 \%$ lethal dose $\left(\mathrm{LD}_{50}\right)$ and

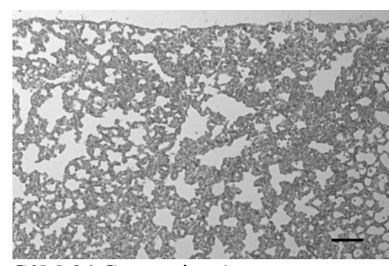

G0M-04 Congestion 1+

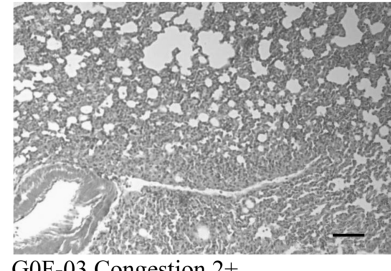

G0F-03 Congestion $2+$

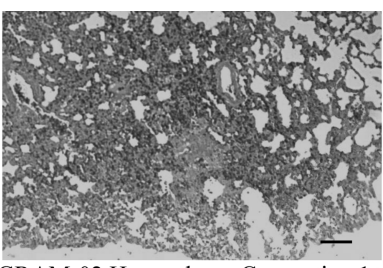

GRAM-02 Hemorrhage-Congestion 1+

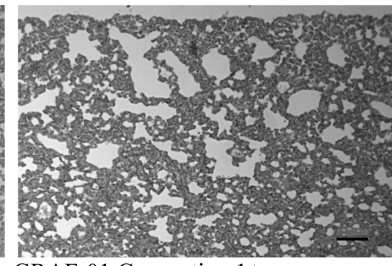

GRAF-01 Congestion 1+
Fig. 1. Histopathological changes detected in the lung. Note that hypertrophy of alveolus as congestion with hemorrhage were randomly detected and dispersed throughout the all tested groups including vehicle control. All Hematoxylin \& Eosin stain; Scale bars $=100 \mu \mathrm{m}$.

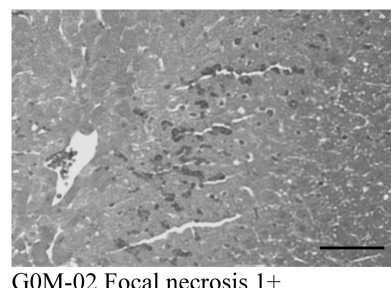

G0M-02 Focal necrosis $1+$
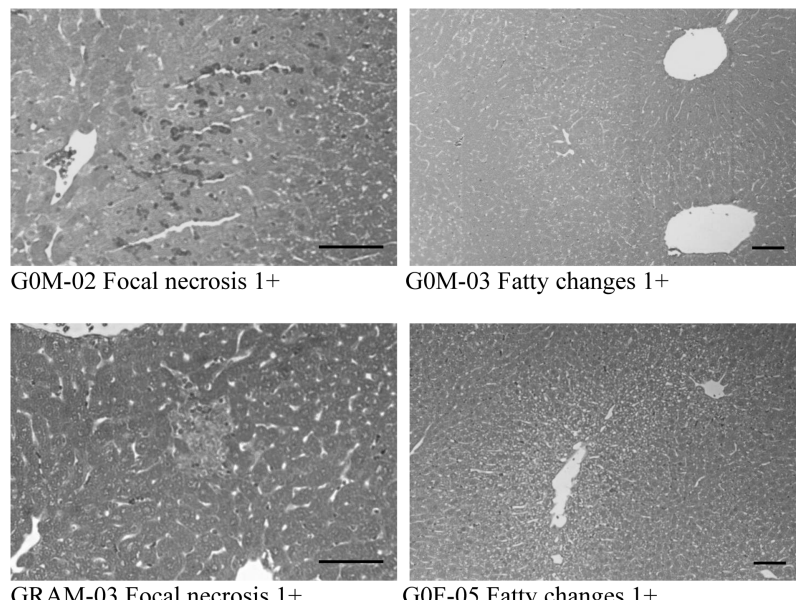

G0M-03 Fatty changes $1+$

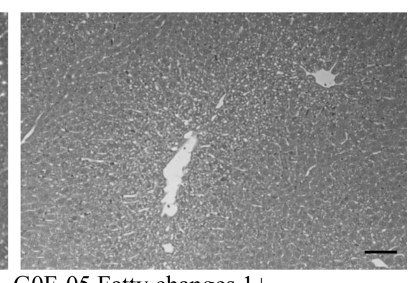

G0F-05 Fatty changes $1+$
Fig. 2. Histopathological changes detected in the liver. Note that fatty changes and necrotic foci were randomly observed including vehicle controls as accidental findings. All Hematoxylin \& Eosin stain; Scale bars $=100 \mu \mathrm{m}$. 
Table IV. Changes in the absolute organ weights observed in female and male mice after a oral dose of RA extracts

\begin{tabular}{|c|c|c|c|c|c|c|c|c|c|c|c|c|}
\hline \multirow[b]{2}{*}{ Group ID } & \multicolumn{12}{|c|}{ Principal Organs } \\
\hline & Lung & Heart & Thymus & $\begin{array}{c}\text { Kidney } \\
\text { L }\end{array}$ & $\begin{array}{l}\text { Adrenal } \\
\text { gland L }\end{array}$ & Spleen & $\begin{array}{c}\text { Testis/ } \\
\text { Ovary L }\end{array}$ & Liver & Pancreas S & Brain & $\begin{array}{l}\text { Epididymis } \\
\text { L/Uterus }\end{array}$ & $\begin{array}{c}\text { Lymph node } \\
\text { L }^{\mathrm{a}}\end{array}$ \\
\hline G0M & $0.208 \pm 0.014$ & $\begin{array}{c}0.176 \pm \\
0.015\end{array}$ & $\begin{array}{c}0.064 \pm \\
0.016\end{array}$ & $\begin{array}{c}0.355 \pm \\
0.059\end{array}$ & $\begin{array}{c}0.008 \pm \\
0.004\end{array}$ & $\begin{array}{c}0.110 \pm \\
0.016\end{array}$ & $\begin{array}{c}0.128 \pm \\
0.025\end{array}$ & $\begin{array}{c}1.739 \pm \\
0.213\end{array}$ & $\begin{array}{c}0.202 \pm \\
0.030\end{array}$ & $\begin{array}{c}0.488 \pm \\
0.013\end{array}$ & $\begin{array}{c}0.044 \pm \\
0.002\end{array}$ & $\begin{array}{c}0.023 \pm \\
0.011\end{array}$ \\
\hline GRAM & $0.210 \pm 0.021$ & $\begin{array}{c}0.191 \pm \\
0.024\end{array}$ & $\begin{array}{c}0.068 \pm \\
0.009\end{array}$ & $\begin{array}{c}0.341 \pm \\
0.069\end{array}$ & $\begin{array}{c}0.009 \pm \\
0.005\end{array}$ & $\begin{array}{c}0.120 \pm \\
0.050\end{array}$ & $\begin{array}{c}0.119 \pm \\
0.008\end{array}$ & $\begin{array}{c}1.772 \pm \\
0.121\end{array}$ & $\begin{array}{c}0.210 \pm \\
0.030\end{array}$ & $\begin{array}{c}0.510 \pm \\
0.018\end{array}$ & $\begin{array}{c}0.044 \pm \\
0.004\end{array}$ & $\begin{array}{c}0.028 \pm \\
0.010\end{array}$ \\
\hline G0F & $0.180 \pm 0.011$ & $\begin{array}{c}0.145 \pm \\
0.015\end{array}$ & $\begin{array}{c}0.072 \pm \\
0.016\end{array}$ & $\begin{array}{c}0.203 \pm \\
0.020\end{array}$ & $\begin{array}{c}0.009 \pm \\
0.003\end{array}$ & $\begin{array}{c}0.124 \pm \\
0.021\end{array}$ & $\begin{array}{c}0.040 \pm \\
0.013\end{array}$ & $\begin{array}{c}1.268 \pm \\
0.112\end{array}$ & $\begin{array}{c}0.178 \pm \\
0.016\end{array}$ & $\begin{array}{c}0.468 \pm \\
0.035\end{array}$ & $\begin{array}{c}0.136 \pm \\
0.032\end{array}$ & $\begin{array}{l}0.022 \pm \\
0.003\end{array}$ \\
\hline GRAF & $0.187 \pm 0.013$ & $\begin{array}{c}0.147 \pm \\
0.008\end{array}$ & $\begin{array}{c}0.069 \pm \\
0.012\end{array}$ & $\begin{array}{c}0.210 \pm \\
0.008\end{array}$ & $\begin{array}{c}0.009 \pm \\
0.002\end{array}$ & $\begin{array}{c}0.119 \pm \\
0.028\end{array}$ & $\begin{array}{c}0.050 \pm \\
0.007\end{array}$ & $\begin{array}{l}1.385 \pm \\
0.153\end{array}$ & $\begin{array}{c}0.195 \pm \\
0.035\end{array}$ & $\begin{array}{c}0.479 \pm \\
0.021\end{array}$ & $\begin{array}{c}0.142 \pm \\
0.038\end{array}$ & $\begin{array}{c}0.025 \pm \\
0.006\end{array}$ \\
\hline
\end{tabular}

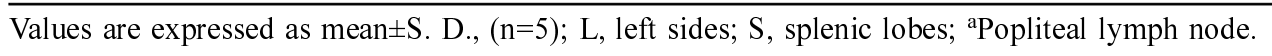

Table V. Changes in the relative organ weights observed in female and male mice after a oral dose of RA extracts

\begin{tabular}{|c|c|c|c|c|c|c|c|c|c|c|c|c|}
\hline \multirow[b]{2}{*}{ Group ID } & \multicolumn{12}{|c|}{ Principal Organs } \\
\hline & Lung & Heart & Thymus & $\begin{array}{c}\text { Kidney } \\
\text { L }\end{array}$ & $\begin{array}{l}\text { Adrenal } \\
\text { gland L }\end{array}$ & Spleen & $\begin{array}{c}\text { Testis/ } \\
\text { Ovary L }\end{array}$ & Liver & Pancreas S & Brain & $\begin{array}{c}\text { Epididymis } \\
\text { L/Uterus }\end{array}$ & $\begin{array}{c}\text { Lymph node } \\
\text { L }^{\mathrm{a}}\end{array}$ \\
\hline G0M & $\begin{array}{c}0.533 \pm \\
0.036\end{array}$ & $\begin{array}{c}0.450 \pm \\
0.030\end{array}$ & $\begin{array}{c}0.161 \pm \\
0.033\end{array}$ & $\begin{array}{c}0.906 \pm \\
0.106\end{array}$ & $\begin{array}{c}0.021 \pm \\
0.010\end{array}$ & $\begin{array}{c}0.282 \pm \\
0.028\end{array}$ & $\begin{array}{c}0.331 \pm \\
0.080\end{array}$ & $\begin{array}{c}4.442 \pm \\
0.309\end{array}$ & $\begin{array}{c}0.516 \pm \\
0.040\end{array}$ & $\begin{array}{c}1.257 \pm \\
0.116\end{array}$ & $\begin{array}{c}0.113 \pm \\
0.006\end{array}$ & $\begin{array}{c}0.059 \pm \\
0.028\end{array}$ \\
\hline GRAM & $\begin{array}{c}0.530 \pm \\
0.053\end{array}$ & $\begin{array}{c}0.482 \pm \\
0.053\end{array}$ & $\begin{array}{c}0.172 \pm \\
0.022\end{array}$ & $\begin{array}{c}0.858 \pm \\
0.151\end{array}$ & $\begin{array}{c}0.024 \pm \\
0.013\end{array}$ & $\begin{array}{c}0.304 \pm \\
0.125\end{array}$ & $\begin{array}{c}0.301 \pm \\
0.028\end{array}$ & $\begin{array}{c}4.465 \pm \\
0.192\end{array}$ & $\begin{array}{c}0.530 \pm \\
0.083\end{array}$ & $\begin{array}{c}1.287 \pm \\
0.061\end{array}$ & $\begin{array}{c}0.112 \pm \\
0.014\end{array}$ & $\begin{array}{c}0.071 \pm \\
0.026\end{array}$ \\
\hline G0F & $\begin{array}{c}0.611 \pm \\
0.034\end{array}$ & $\begin{array}{c}0.491 \pm \\
0.035\end{array}$ & $\begin{array}{c}0.243 \pm \\
0.065\end{array}$ & $\begin{array}{c}0.688 \pm \\
0.051\end{array}$ & $\begin{array}{c}0.030 \pm \\
0.009\end{array}$ & $\begin{array}{c}0.421 \pm \\
0.062\end{array}$ & $\begin{array}{c}0.135 \pm \\
0.048\end{array}$ & $\begin{array}{c}4.302 \pm \\
0.327\end{array}$ & $\begin{array}{c}0.605 \pm \\
0.043\end{array}$ & $\begin{array}{c}1.588 \pm \\
0.065\end{array}$ & $\begin{array}{c}0.460 \pm \\
0.101\end{array}$ & $\begin{array}{c}0.075 \pm \\
0.009\end{array}$ \\
\hline GRAF & $\begin{array}{c}0.583 \pm \\
0.021\end{array}$ & $\begin{array}{c}0.457 \pm \\
0.022\end{array}$ & $\begin{array}{c}0.215 \pm \\
0.030\end{array}$ & $\begin{array}{c}0.656 \pm \\
0.034\end{array}$ & $\begin{array}{c}0.027 \pm \\
0.003\end{array}$ & $\begin{array}{c}0.369 \pm \\
0.065\end{array}$ & $\begin{array}{c}0.154 \pm \\
0.019\end{array}$ & $\begin{array}{c}4.304 \pm \\
0.270\end{array}$ & $\begin{array}{c}0.604 \pm \\
0.082\end{array}$ & $\begin{array}{c}1.493 \pm \\
0.077\end{array}$ & $\begin{array}{c}0.446 \pm \\
0.130\end{array}$ & $\begin{array}{c}0.078 \pm \\
0.020\end{array}$ \\
\hline
\end{tabular}

Values are expressed as mean \pm S. D., $(n=5)$; L, left sides; $S$, splenic lobes; ${ }^{\text {PPopliteal lymph node. }}$ 
approximate lethal dosage (LD), test substances were administered orally to female and male ICR mice at dose levels of 2000 $\mathrm{mg} / \mathrm{kg}$. However, we could not find any mortality, abnormal signs, significant changes in the body weight and gross observation except for increase of hypertrophy of lymph nodes in male RA extracts-dosing group. In addition, no RA extractstreatment related abnormal changes were noted in the organ weight and histopathology of principle organs except for some sporadic accidental findings.

No RA extracts related histopathological changes were detected in lymph nodes, although the hypertrophy of lymph nodes was detected as one of accidental findings. The hyperplasia of lymphoid cells and follicles were frequently observed after treatment of immune enhancers (Lee et al., 2005), with increase in the weights of spleen or lymphatic organs (Klein et al., 1987; Iqbal et al., 2001). However, RA extracts only increase the incidences of the hypertrophy.

In KFDA Guidelines (2005-60, 2005), the recommended highest dose of test materials is $2000 \mathrm{mg} / \mathrm{kg}$ or the maximum solubility in a volume below $20 \mathrm{ml} / \mathrm{kg}$ for studies of acute toxicity in mice. In the present study, the highest dose of RA extracts was selected as $2000 \mathrm{mg} / \mathrm{kg}$ because RA extracts have been used as folk medicine and ingredients of medicinal food for long times and no revealed toxicological data was available.

Hair loss detected in this study were not RA extracts-treatment related signs because they were also detected in the vehicle control with higher frequencies encounted. Congestion spots of lung, atrophy of thymus, cyst and discolorization of kidney and spleen atrophy detected as gross findings, and hypertrophy of lung alveolus wall with hemorrhage, focal necrotic foci and fatty changes in liver detected as histopathological findings were also considered as accidental findings, and they were not considered as RA extracts-treatment related abnormal gross or histopathological findings because they were restricted in some individual animals and most of the case, also observed in vehicle control. In addition, most of them were rarely observed in normal mice (Lee et al., 2005; Lee et al., 2006).

Hodge and Sterner (1949) classify as non toxic materials for those with $\mathrm{LD}_{50}$ of $5000 \sim 15000 \mathrm{mg} / \mathrm{kg}$ and those with $\mathrm{LD}_{50}$ of $500 \sim 5000 \mathrm{mg} / \mathrm{kg}$ as relatively low toxic (Class III) in US environmental Protection Agency (OPPTS 870.100; 1998). However, recent guideline by Korean Food and Drug Administration (2005-60, 2005) recommended that the highest oral dose of test materials should be $2000 \mathrm{mg} / \mathrm{kg}$. The $\mathrm{LD}_{50}$ and approximate LD in mice after single oral dose of RA extracts
Table VI. Necropsy findings in female and male mice after once orally dose of RA extracts

\begin{tabular}{lcccc}
\hline \multirow{2}{*}{ Group ID } & \multicolumn{2}{c}{ MALE } & \multicolumn{2}{c}{ FEMALE } \\
\cline { 2 - 5 } & G0M & GRAM & G0F & GRAF \\
\hline Lung & $2 / 5$ & $1 / 5$ & $3 / 5$ & $0 / 5$ \\
$\quad \begin{array}{l}\text { Congestion } \\
\text { Thymus } \\
\quad \text { Atrophy }\end{array}$ & $2 / 5$ & $0 / 5$ & $1 / 5$ & $0 / 5$ \\
$\begin{array}{l}\text { Kidney } \\
\quad \text { Cyst }\end{array}$ & $0 / 5$ & $1 / 5$ & $1 / 5$ & $1 / 5$ \\
$\quad$ Discolorization & $1 / 5$ & $1 / 5$ & $1 / 5$ & $0 / 5$ \\
$\quad \begin{array}{l}\text { Spleen } \\
\quad \text { Atrophy }\end{array}$ & $2 / 5$ & $2 / 5$ & $1 / 5$ & $1 / 5$ \\
$\begin{array}{l}\text { Politeal lymph node } \\
\quad \text { Hypertrophy }\end{array}$ & $2 / 5$ & $4 / 5$ & $1 / 5$ & $1 / 5$ \\
\hline
\end{tabular}

Values are expressed as observed animals/total observed animals $(\mathrm{n}=5)$

Table VII. Histopathological findings in female and male mice after once orally dose of RA extracts

\begin{tabular}{lcccc}
\hline \multirow{2}{*}{ Group ID } & \multicolumn{2}{c}{ MALE } & \multicolumn{2}{c}{ FEMALE } \\
\cline { 2 - 5 } & G0M & GRAM & G0F & GRAF \\
\hline Lung & $3 / 5$ & $3 / 5$ & $2 / 5$ & $1 / 5$ \\
Congestion & $0 / 5$ & $1 / 5$ & $0 / 5$ & $0 / 5$ \\
Hemorrhage & & & & \\
Liver & $1 / 5$ & $1 / 5$ & $0 / 5$ & $0 / 5$ \\
$\quad$ Focal necrosis & $2 / 5$ & $0 / 5$ & $1 / 5$ & $0 / 5$ \\
$\quad$ Fatty changes &
\end{tabular}

Values are expressed as observed animals/total observed animals $(\mathrm{n}=5)$

were detected over $2000 \mathrm{mg} / \mathrm{kg}$ in both male and female in the present study. Therefore, oral administration of RA extracts caused no serious toxic effect to the male and female mice upto $2000 \mathrm{mg} / \mathrm{kg}$ - the highest dosage tested in this study and is likely to be safe in humans.

\section{ACKNOWLEDGMENTS}

This research was supported by a grant (PF06217-02) from Plant Diversity Research Center of 21st Century Frontier Research Program funded by Ministry of Science and Technology of Korean government.

\section{REFERENCES}

Dourish, C.T. (1987). Effects of drugs on spontaneous motor activity. In Experimental Psychopharmacology (A.J. Greenshaw and C.T. Dourish, Ed.), pp. 325-334. Humana Press, Clifton.

Hodge, H.C. and Sterner, J.H. (1949). Tabulation of toxicity 
classes. Am. Ind. Hyg. Q. 10, 93.

Iqbal, M.P., Sultana, F., Mehboobali, N. and Pervez, S. (2001). Folinic acid protects against suppression of growth by methotrexate in mice. Biopharm. Drug Dispos. 22, 169-178.

Irwin, S. (1968). Comprehensive observational assessment: Ia. A systemic, quantitative procedure for assessing the behavioral and physiological state of the mouse. Psychopharmacology 13, 222-257.

Klein, H.O., Kreysch, H.G., Coerper, C., Voigt, P. and Ruff, I. (1987). Preclinical and early clinical trial with mafosfamide as immune modulator. Methods Find Exp. Clin. Pharmacol. 9, 627-640.

Korea Food and Drug Administration (2005): Testing Guidelines for Safety Evaluation of Drugs (Notification No. 2005-60, issued by the Korea Food and Drug Administration on October 21, 2005).

Lee, G.I., Ha, J.Y., Min, K.R., Nakagawa, H., Tsurufuji, S., Chang, I.M. and Kim, Y. (1995). Inhibitory effects of Oriental herbal medicines on IL-8 induction in lipopolysaccharide-activated rat macrophages. Planta Med. 61, 26-30.

Lee, H.S., Lee I.G. and Ku S.K. (2006). Single oral dose toxicity study of water extracts of Picrorrhiza Rhizoma in mice. $J$. Toxicol. Pub. Health 22, 117-126.

Lee, J.E., Kim, H.J., Choi, E.K, Chai, H.Y., Yun, Y.W., Kim, D.J., Nam, S.Y., Lee, B.J., Ahn, B.W., Kang, H.G. and Kim, Y.B. (2003). Four-week repeated-dose toxicity study on Pinellia Extract. Korean J. Lab. Anim. Sci. 19, 127-141.

Lee, J.H, Yang, K.J., Shin, H.D., Park, B.R., Son, C.W., Jang, H.J., Park, D.C., Lee, H.S. and Ku, S.K. (2005). Single subcutaneous dose toxicity of Polycan ${ }^{\circledR}$, a $\beta$-glucan originated from Aureobasidium in mice. Lab. Anim. Res. 21, 299-305.

Park, H.J., Hong, M.S., Lee, J.S., Leem, K.H., Kim, C.J., Kim, J.W. and Lim, S. (2005). Effects of Aralia continentalis on hyperalgesia with peripheral inflammation. Phytother. Res. 19, 511-513.

US Environmental Protection Agency (1998). Health Effects Test Guidelines OPPTS 870.100, Acute Toxicity Testing Background. US EPA August, Washington, USA.

Wang, G.S., Shao, C.J. and Xu, J.D. (1989). Studies on the chemical constituents of the roots of Aralia continentalis Kitag. Zhongguo Zhong Yao Za Zhi 14, 422-424, 447. 